\section{Performance of Sweetpotato Foundation Seed after Incorporation into Commercial Operations in Louisiana}

\author{
Christopher A. Clark ${ }^{1,3}$, Tara P. Smith ${ }^{2}$, Donald M. Ferrin ${ }^{1}$, \\ and Arthur Q. Villordon ${ }^{2}$
}

AdDITIONAL INDEX WORDs. Ipomoea batatas, virus-tested technology, 'Beauregard', cultivar yield decline, virus indexing, sweet potato feathery mottle virus, sweet potato virus $G$, sweet potato virus 2

SUMmARY. Because sweetpotato (Ipomoea batatas) is vegetatively propagated, viruses and mutations can accumulate readily, which can lead to cultivar decline. Sweetpotato foundation seed programs in the United States maintain the integrity of commercial seed stock by providing virus-tested (VT) foundation seed to commercial producers. A survey was conducted in Louisiana from 2007 to 2009 to examine the performance and quality of the foundation seed after it had been integrated into commercial sweetpotato operations. Gl seed [grown 1 year after virus therapy in the foundation seed production field at the Sweet Potato Research Station, Louisiana State University Agricultural Center (LSU AgCenter), at Chase, LA] was used as a reference to compare the yield and virus incidence of growers' generation 2 (G2) and generation 3 (G3) seed roots (grown in the growers' seed production fields 1 or 2 years following the year of foundation seed production). Although yields of plants grown from G2 and G3 seed were $86.3 \%$ and $86.1 \%$ for U.S. No. 1 and $83.3 \%$ and $\mathbf{8 6 . 0 \%}$ for total marketable, respectively, compared with the yields from Gl seed, they were not significantly different. Yield and virus incidence data suggest that seed quality may vary from year to year and from location to location. Results from this study suggest that producers are realizing yield benefits by incorporating VT foundation seed into their production schemes, but further benefits could be attained if ways to reduce re-infection with viruses can be found.

S weetpotato is gaining increasing importance in the United States as the health-conscious consumers and the availability of value-added processed products have increased demand. Per capita consumption of the crop increased over $24 \%$ from 1998 to 2008 , and the value of the U.S. crop in 2009 exceeded $\$ 400$ million [Lucier and Dettman, 2008; U.S. Department of Agriculture (USDA), 2010]. In 2009, 19.6 million cwt of sweetpotatoes were produced on 97,700

Approved for publication by the director of the Louisiana Agricultural Experiment Station as manuscript no. 6783 .

We thank all Louisiana sweetpotato producers who provided foundation seed for this research project. We greatly appreciate the assistance of Mary Hoy with virus indexing and harvesting of research plots.

Mention of trademark, proprietary product or method, and vendor does not imply endorsement by the Louisiana State University Agricultural Center or its approval to the exclusion of other suitable products or vendors.

${ }^{1}$ Department of Plant Pathology and Crop Physiology, Louisiana State University Agricultural Center, 302 Life Sciences Building, Baton Rouge, LA 70803

${ }^{2}$ Sweet Potato Research Station, Louisiana State University Agricultural Center, 130 Sweet Potato Road, P.O. Box 120, Chase, LA 71324

${ }^{3}$ Corresponding author. E-mail: cclark@agcenter.lsu. edu. acres (USDA, 2010). However, the cost of production is high, requiring that growers optimize production and quality (Hinson and Boudreaux, 2009; Stoddard et al., 2006).

Since sweetpotato is vegetatively propagated, systemic pathogens, especially viruses, can accumulate in the propagative material, leading to decline in the performance of cultivars (Bryan et al., 2003a, 2003b; Clark et al., 2002). Estimates suggest that yields of the cultivar Beauregard can be reduced by as much as $25 \%$ to $40 \%$ (Bryan et al., 2003a, 2003b; Carroll et al., 2004; Clark and Hoy, 2006). To counter cultivar decline, major sweetpotatogrowing states have developed foundation seed programs that provide "VT" (indexed by grafting to an indicator host, by assaying for specific viruses, or by both and found to be apparently free of known viruses) seed to growers. La Bonte et al. (2004) compared different generations of 'Beauregard' produced from small research plots and found increased yields for G2, but not for other generations. However, seed produced from small plots located in large fields of infected material does not represent the same probability for reinfection with viruses as on farms where larger blocks of seed are produced.

The state foundation seed programs all rely on the use of meristemtip culture and indexing to generate VT tissue culture plantlets, but the methods for subsequent increase and dissemination of clean stock to growers differ from state to state (Dangler, 1994). In Louisiana, VT tissue cultures are increased by nodal propagation and the plantlets are planted in greenhouses at Sweet Potato Research Station, LSU AgCenter, at Chase in December of each year. The plants in the greenhouses are increased by vine cuttings through the winter, and these plants are used as a source of vine cuttings to plant production fields the following summer. The roots harvested from these fields are sold to growers as foundation seed and represent the first generation from the field or Gl seed. Growers, thus, rely on this sole source of Gl seed to begin the seed program on their farms. They produce

\begin{tabular}{llll}
\hline $\begin{array}{l}\text { Units } \\
\text { To convert U.S. } \\
\text { to SI, multiply by }\end{array}$ & U.S. units & SI units & $\begin{array}{l}\text { To convert SI to } \\
\text { U.S., multiply by }\end{array}$ \\
\hline 10 & $\%$ & $\mathrm{~g} \cdot \mathrm{L}^{-1}$ & 0.1 \\
0.4047 & $\mathrm{acre}(\mathrm{s})$ & $\mathrm{ha}$ & 2.4711 \\
45.3592 & $\mathrm{cwt}$ & $\mathrm{kg}$ & 0.0220 \\
29,574 & $\mathrm{fl} \mathrm{oz}$ & $\mu \mathrm{L}$ & $3.3814 \times 10^{-5}$ \\
29.5735 & $\mathrm{fl} \mathrm{oz}$ & $\mathrm{mL}$ & 0.0338 \\
3.7854 & $\mathrm{gal}$ & $\mathrm{L}$ & 0.2642 \\
2.54 & inch $(\mathrm{es})$ & $\mathrm{cm}$ & 0.3937 \\
6.4516 & inch & $\mathrm{cm}$ & 0.1550 \\
0.4536 & $\mathrm{lb}$ & $\mathrm{kg}$ & 2.2046 \\
4.8824 & $\mathrm{lb} / 1000 \mathrm{ft}^{2}$ & $\mathrm{~g} \cdot \mathrm{m}^{-2}$ & 0.2048 \\
1.1209 & $\mathrm{lb} / \mathrm{acre}$ & $\mathrm{kg} \cdot \mathrm{ha}^{-1}$ & 0.8922 \\
28.3495 & $\mathrm{oz}$ & $\mathrm{g}$ & 0.0353 \\
28,350 & $\mathrm{Oz}$ & $\mathrm{mg}$ & $3.5274 \times 10^{-5}$ \\
0.001 & $\mathrm{ppm}$ & $\mathrm{g} \cdot \mathrm{L}^{-1}$ & 1000 \\
$\left({ }^{\circ} \mathrm{F}-32\right) \div 1.8$ & ${ }^{\circ} \mathrm{F}$ & ${ }^{\circ} \mathrm{C}$ & $\left(1.8 \times{ }^{\circ} \mathrm{C}\right)+32$ \\
& & &
\end{tabular}

Horflechnology • December $201020(6)$ 
a G2 crop, which they use the following year for production of their commercial crop. Thus, the commercial crop is usually grown from G2 seed roots, or in some cases, if supplies of G2 are inadequate, also from G3 seed. Bryan et al. (2003a) suggested that in North Carolina, where commercial certified seed growers produce G2 seed for sale to table-stock growers, the greatest net return for sweetpotatoes derives from using G2 plants as the cost for producing G2 plants is much lower than that for producing Gl seed, while the yield and quality remain relatively high. Although growers are encouraged to isolate their seed production from the rest of their commercial production, it is often difficult for them to do this because of the limited availability of land. Management programs for virus vectors have not been developed for sweetpotato in Louisiana (Hammond et al., 2001), and growers have few options for preventing reinfection of their seed. Preliminary evaluations indicated that low incidence of re-infection with viruses can occur during the production of $\mathrm{Gl}$ foundation seed. However, there was little information available to evaluate how rapidly seed productivity and quality declined during the increase of seed on farms, where older generations of sweetpotato are also grown and could serve as sources of inoculum for reinfection of new seed. This study was conducted to evaluate changes in quality of seed from different farms in the major sweetpotato production areas of Louisiana to better understand how rapidly seed declines overall and to determine if location of seed production affects decline.

\section{Materials and methods}

Field sTudies. Virus-tested foundation 'Beauregard' seed (Gl) was obtained from the Sweet Potato Research Station, LSU AgCenter, at Chase. This is the only source of Gl seed roots in Louisiana, and each of the participating farmers bought foundation seed from this source to produce their subsequent generations of seed. Five growers from northern Louisiana and five growers from southern Louisiana participated each year of the study, providing one $40-\mathrm{lb}$ box each of "seed" roots to represent their newest seed (G2) and their oldest seed (G3 or G4). Thus, each farm represented a line of descent from the same initial source. Different mericlones of 'Beauregard' were used depending on what the growers used for their production: 1 "seed" sample of mericlone B-7, 7 samples of B-14, and 12 samples of B-63 in 2007; 9 samples of B-14 and 14 samples of B-63 in 2008; and 8 samples of B-14 and 10 samples of B-63 in 2009. The seed were bedded at the LSU AgCenter Burden Center in Baton Rouge in mid-March each year by laying the roots in an open furrow, spraying dicloran (Botran 75W; Gowan, Yuma, AZ) at $2.25 \mathrm{lb} / 1000 \mathrm{ft}^{2}$ onto the roots laid out in the beds, covering the roots with soil to a depth of $\approx 1-2$ inches above the top of the roots, and covering the beds with black plastic mulch. Within $2 \mathrm{~d}$ of bedding, holes were punched in the mulch to allow aeration, and the mulch was removed in mid-April each year. As soon as the mulch was removed, each bed was covered with rowcover (AgroFabric 19; American Agrifabrics, Alpharetta, GA) on hoops over the row to reduce movement of insect vectors among beds. The plant beds were not irrigated. In mid-May of each year, slips were cut from the bed by hand by cutting the plants $\approx \mathrm{l}$ inch above the soil. The slips were subsequently sorted, and only plants 10-12 inches in length and 3/8 inch in diameter with a terminal bud were used for transplanting.

The slips cut from the beds were used to plant plots to compare yields at the Burden Center on 15th, 13th, and 20th May of 2007, 2008, and 2009, respectively. The plots consisted of five replications of single-row, 25-plant plots arranged in a randomized complete block design. Plots were prepared for planting by incorporating into the soil $400 \mathrm{lb} /$ acre of $8 \mathrm{~N}-10.5 \mathrm{P}-19.9 \mathrm{~K}$, bifenthrin (Brigade 2EC; Food Machinery and Chemical Corporation, Philadelphia, PA) at $0.05 \mathrm{lb} /$ acre (to reduce soil insects), and imidacloprid (a systemic insecticide to reduce populations of virus vectors; Merit $0.5 \mathrm{G}$, Bayer Environmental Science, Research Triangle Park, NC) at $0.4 \mathrm{lb} /$ acre. The rows were then hipped, and a bed shaper was used to make ridged rows about 12 inches high and 48 inches apart, center to center. Transplants were inserted into the ground with the aid of notched sticks so that two nodes were below ground and were then immediately watered by hand. In accordance with the standard sweetpotato weevil (Cylas formicarius) control procedures, following a lay-by application of bifenthrin at $0.05 \mathrm{lb} /$ acre, the plots were sprayed on a weekly basis alternating phosmet (Imidan 70WP, Gowan) at $0.93 \mathrm{lb} /$ acre $+4.5 \mathrm{~mL} /$ gal Latron buffer (Rohm and Haas, Philadelphia, PA), methyl parathion (PennCap M; United Phosphorus, King of Prussia, PA) at $0.5 \mathrm{lb} / \mathrm{acre}$, and endosulfan (Thiodan 3EC; Food Machinery and Chemical Corporation) at $0.75 \mathrm{lb} /$ acre. Plots were harvested on 22 Aug. 2007 [99 d after transplanting (DAT)], 28 Aug. 2008 (107 DAT), and 4 Sept. 2009 (107 DAT) with the aid of a single-row chain digger that lifted the roots and dropped them back onto the soil surface. The roots were sorted in the field into USDA standard grades based on the size: U.S. No. $1=$ roots $2-31 / 2$ inches in diameter and 3-9 inches in length; canner $=$ roots $1-2$ inches in diameter and 2-7 inches in length; jumbo = roots that exceed the diameter, length, and weight requirements of the U.S. No. 1 and canner grades; and total marketable $=$ sum of U.S. No. 1, canner, and jumbo grades (USDA, 2005).

VIRUS INDEXING. In 2007 and 2009 , extra vine cuttings were collected from the beds at the time of transplanting the yield plots and indexed to determine the incidence of virus infection. Twelve and six cuttings per seed lot were indexed in 2007 and 2009, respectively. A two-node segment of vine from the basal portion of the cutting was wedge grafted as a scion onto a seedling of the brazilian morning glory (Ipomoea setosa). The grafted plants were grown in a greenhouse for 2 weeks when the proportion of plants with symptoms indicative of virus infection (vein clearing, chlorotic spotting, and chlorotic vein banding) was recorded as an indicator of infection with one or more viruses. Leaf tissues were collected from symptomatic plants and assayed by nitrocellulose membrane-enzyme-linked immunosorbent assay (NCM-ELISA) using antisera produced to the russet crack strain of sweet potato feathery mottle virus (SPFMV), provided by J.W. Moyer (North Carolina State University, Raleigh), or antisera to isolates from Louisiana of sweet potato virus $\mathrm{G}$ (SPVG) and sweet potato virus 2 (SPV2, synonym = ipomoea vein mosaic virus). A small piece $\left(\approx 1 \mathrm{~cm}^{2}\right)$ was collected from a lower, middle, and upper leaf of each brazilian morning glory plant, combined, 
placed in a "Universal" extraction bag (article no. 430100; BIOREBA, Reinach, Switzerland), and homogenized using a HOMEX 6 homogenizer (BIOREBA) in $8 \mathrm{~mL}$ of tris-buffered saline [TBS $(0.02 \mathrm{M}$ Tris base, $0.50 \mathrm{M}$ $\mathrm{NaCl}) ; \mathrm{pH} 7.5]$ containing $0.2 \%$ of sodium sulfite $\left(\mathrm{Na}_{2} \mathrm{SO}_{3}\right)$. Two milliliters of the extracted tissue was transferred to a $2-\mathrm{mL}$ microfuge tube and allowed to stand for $30-45 \mathrm{~min}$ at room temperature. The clarified sap extract $(50 \mu \mathrm{L})$ was blotted onto a TBS-saturated nitrocellulose membrane and air-dried for 20-30 min. All the incubations and washings were done at room temperature in a shaker with gentle agitation $(50 \mathrm{rpm}$ for incubations and $100 \mathrm{rpm}$ for washings). The membranes were blocked with TBS containing $2 \%$ powdered milk and 2\% Triton X-100 (Sigma-Aldrich, St Louis, MO) and incubated for $1 \mathrm{~h}$. The blocking solution was discarded, and the membranes rinsed with $\mathrm{T}$ TBS [TBS containing 0.05\% Tween 20 (Sigma-Aldrich)]. The first antibody (polyclonal antibody specific to SPFMV, SPVG, and SPV2) was crossabsorbed in healthy brazilian morning glory extract $[1 \mathrm{~g}$ of tissue homogenized in $25 \mathrm{~mL}$ of TBS containing $2 \mathrm{~g} \cdot \mathrm{L}^{-1}$ sodium sulfite, $20 \mathrm{~g} \cdot \mathrm{L}^{-1} \mathrm{Car}-$ nation skim milk (Nestlé USA, Solon, $\mathrm{OH}$ ), and $0.2 \mathrm{~g} \cdot \mathrm{L}^{-1}$ sodium azide; $\mathrm{pH}$ 7.5 ] for $45 \mathrm{~min}$ at $37^{\circ} \mathrm{C}$ and was then added to the membranes and incubated overnight. The membranes were washed in T-TBS four times for $3 \mathrm{~min}$ each. The second antibody (goat antirabbit), conjugated with alkaline phosphatase and diluted in TBS containing $2 \%$ powdered milk, was added to the membranes and incubated for $\mathrm{l} \mathrm{h}$. The membranes were washed as before, and the presence of bound antibody was visualized by the addition of substrate solution [ $10 \mathrm{mg}$ of nitrobenzene tetrazolium in $100 \mu \mathrm{L}$ of dimethyl formamide, followed by $5 \mathrm{mg}$ of 5 bromo-3-chloro indolyl phosphate in $100 \mu \mathrm{L}$ of dimethyl formamide added to $30 \mathrm{~mL}$ of substrate buffer $(0.1 \mathrm{M}$ Tris $\mathrm{HCl}, 0.1 \mathrm{M} \mathrm{NaCl}, 5 \mathrm{~mm} \mathrm{MgCl}_{2}$; $\mathrm{pH}$ 9.5)]. The color reaction was stopped after $30 \mathrm{~min}$ by washing with deionized water. Positive reactions were determined by visual assessment, and a purple color reaction was recorded as positive. Percent total infection was the percent of plants that formed a compatible graft in brazilian morning glory that developed symptoms and percent infection with each individual virus was based on NCM-ELISA results.

Statistical analysis. Since there was a single source of Gl seed, it was used as a reference to compare yields of G2 and G3 seed; G4 seed was excluded from the analysis for lack of samples from each farm. Yields of G2 and G3 plots were converted to a proportion of the mean yield of Gl plots of the corresponding mericlone. Yields were tested for normality using the RyanJoiner procedure in Minitab (release 14; Minitab, State College, PA), and the yields of U.S. No. 1 grade and total marketable yield were included in analyses; yields for canner and jumbo grades were not normally distributed and therefore not analyzed. Percentages for virus incidence data were converted by square root arcsin transformation before statistical analysis. Data were analyzed using SAS (version 9.1; SAS Institute, Cary, NC) Mixed Models procedure with year, generation (Gen), region
$(\mathrm{N} / \mathrm{S})$, and mericlone as fixed effects and farm as a random effect.

\section{Results and discussion}

Sweetpotatoes are rapidly reinfected with SPFMV under field conditions (Bryan et al., 2003a; Valverde et al., 2007). In this study, incidence of virus infection, as determined by indexing on brazilian morning glory, was relatively low in Gl seed in 2007 $(20 \%)$, whereas it was relatively high in $2009(84 \%)$, virtually all of which was the result of SPFMV infection (Fig. 1). G2 and subsequent generations of seed had essentially $100 \%$ infection with SPFMV in all years. Bryan et al. (2003a) also found that SPFMV reinfected all VT plants in test plots in North Carolina fields by the end of the growing season. Although SPFMV spreads rapidly in the crop, studies of the effects of different viruses artificially inoculated into VT seed (Clark and Hoy, 2006) indicate that it does not have a major impact on yield.
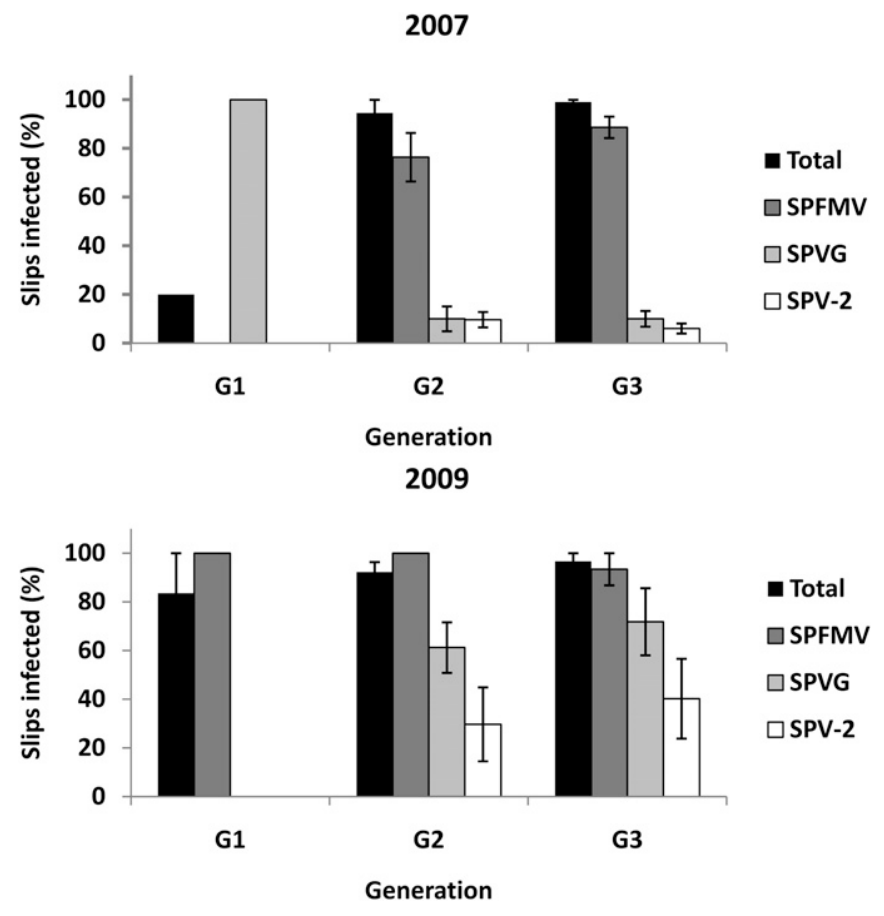

Fig. 1. Mean percentage of sweetpotato slips, by generation, that induced symptoms when grafted onto seedlings of brazilian morning glory indicating total virus infection (total), and percentage of symptomatic brazilian morning glory test plants that tested positive by nitrocellulose membrane-enzyme-linked immunosorbent assay using antisera for sweet potato feathery mottle virus (SPFMV), sweet potato virus G (SPVG), or sweet potato virus 2 (SPV2). G1 represents the foundation seed produced during the first year in the field at the Sweet Potato Research Station (Chase, LA); G2 and G3 represent seed produced by growers after 1 and 2 subsequent years in the field on their farms, respectively. Mean of 12 plants per seed sample in 2007 and of 6 plants per seed sample in 2009 is given (error bars = SE; where no error bars are shown, all samples were $100 \%$ infected). 
Incidence of infection by the other potyviruses assessed in this study, SPVG and SPV2, increased more gradually in later generations of seed (Fig. 1), but were not significantly different between G2 and G3 (Table 1).

Although yields of plants grown from G2 and G3 seed were $86.3 \%$ and $86.1 \%$ for U.S. No. 1 and $83.3 \%$ and $86.0 \%$ for total marketable, respectively, compared with the yields from Gl seed for the three years of this study (Fig. 2), they were not significantly different from each other (Table 1). Inoculation studies indicate that twoand three-way combinations of these viruses with SPFMV caused $14 \%$ to $18 \%$ reduction in yields (Clark and Hoy, 2006), which is comparable to the yields of $\mathrm{G} 2$ and $\mathrm{G} 3$ compared with Gl in this study. This suggests that reinfection with SPVG and SPV2 mostly occurs during the first year seed is increased on commercial farms, which may explain the similarity in yields between G2 and G3. However, studies on the effects of viruses on yields of 'Beauregard' that were done before the advent of VT seed programs showed yield reductions of as much as $25 \%$ to $40 \%$ (Bryan et al., 2003a, 2003b; Carroll et al., 2004; Clark and Hoy, 2006). There is preliminary evidence that suggests there may be one or more as-yet unidentified viruses in sweetpotato (Valverde et al., 2007) that might also contribute to yield decline. Potyviruses are transmitted by aphids in a non-persistent manner and spread rapidly in the field compared with many other plant viruses. It is possible that the putative unknown viruses are less efficiently transmitted and therefore not common in the seed used by growers since the advent of VT seed technology.

Symptoms of russet crack were not observed in any of the seed lots at the time of harvest. However, in some environments, russet crack incidence on 'Beauregard' is greater on old seed (Jester et al., 1994). Since russet crack makes sweetpotatoes unsalable, where russet crack occurs commonly, the value of different generations of seed might be determined more by russet crack incidence than by yield alone.

The influence of mericlone on sweetpotato yield and quality has been described previously (Villordon et al., 2003). Over the 3 years of this study, there were no significant differences in yield or virus infection between the
Table 1. Probabilities determined using SAS Proc Mixed Models (SAS Institute, Cary, NC) analysis for influence of different parameters and interactions of parameters on the yield of U.S. No. 1 and total marketable yield (TMY) of 'Beauregard' sweetpotato as a proportion of yields of comparable Gl ( 1 year in the field) foundation seed from the 3 years of the seed survey and incidence of virus infection from years 2007 and 2009.

\begin{tabular}{|c|c|c|c|c|c|c|}
\hline \multirow[b]{2}{*}{ Parameters } & \multicolumn{2}{|c|}{ Yield $^{\mathrm{z}}$} & \multicolumn{4}{|c|}{ Virus infection } \\
\hline & U.S. No. 1 & TMY & Total $^{\mathrm{y}}$ & SPFMV $^{\mathrm{x}}$ & SPVG $^{x}$ & SPV2 $^{x}$ \\
\hline Year & 0.0039 & 0.0062 & 0.4093 & 0.0403 & $<0.0001$ & 0.3669 \\
\hline Generation $(\text { Gen })^{\mathrm{w}}$ & 0.6023 & 0.2204 & 0.8103 & 0.2772 & 0.9437 & 0.6643 \\
\hline Mericlone $(\text { Meri })^{\mathrm{v}}$ & 0.7439 & 0.4757 & 0.6432 & 0.9150 & 0.2550 & 0.7654 \\
\hline Region $(\mathrm{N} / \mathrm{S})^{\mathrm{u}}$ & 0.0239 & 0.1585 & 0.2469 & 0.6216 & 0.8905 & 0.5956 \\
\hline Year $\times$ Gen & 0.3677 & 0.0991 & 0.7984 & 0.3492 & 0.9152 & 0.8439 \\
\hline Year $\times N / S$ & 0.1517 & 0.4069 & 0.7927 & 0.6134 & 0.4481 & 0.4555 \\
\hline Year $\times$ Meri & 0.4895 & 0.3629 & 0.8725 & 0.8251 & 0.1707 & 0.7903 \\
\hline Gen $\times N / S$ & 0.9078 & 0.7738 & 0.8452 & 0.6450 & 0.3533 & 0.3174 \\
\hline Gen $\times$ Meri & 0.4816 & 0.9728 & 0.8693 & 0.9414 & 0.8536 & 0.4241 \\
\hline
\end{tabular}

${ }^{2}$ U.S. Department of Agriculture standard grades based on size: U.S. No. 1 = roots $2-31 / 2$ inches in diameter and $3-$ 9 inches in length; canner = roots $1-2$ inches in diameter and 2-7 inches in length; jumbo = roots that exceed the diameter, length, and weight requirements of the U.S. No. 1 and canner grades; and TMY $=$ sum of U.S. No. 1, canner, and jumbo grades $(\mathrm{l}$ inch $=2.54 \mathrm{~cm}$ ).

yTotal infection was determined as the percentage of plants that induced symptoms when grafted into brazilian morning glory.

${ }^{\mathrm{x}}$ Infection by each individual virus (SPFMV = sweet potato feathery mottle virus, SPVG = sweet potato virus G, and SPV2 = sweet potato virus 2) was determined as the percentage of plants that gave positive reaction by nitrocellulose membrane-enzyme-linked immunosorbent assay in the corresponding brazilian morning glory index plant.

"Gl represents the foundation seed produced during the first year in the field at the Sweet Potato Research Station (Chase, LA); G2 and G3 represent seed produced by the growers after 1 and 2 subsequent years in the field on their farms, respectively. Yields of G2 and G3 were compared as a proportion of yields of G1.

"A mericlone is derived during meristem-tip culture from a single meristem. Two mericlones of 'Beauregard', B-14, and B-63, are routinely used in sweetpotato production in Louisiana and were represented in this study.

${ }^{\mathrm{u}} \mathrm{N} / \mathrm{S}=$ seed was obtained from farms in northern or southern Louisiana.

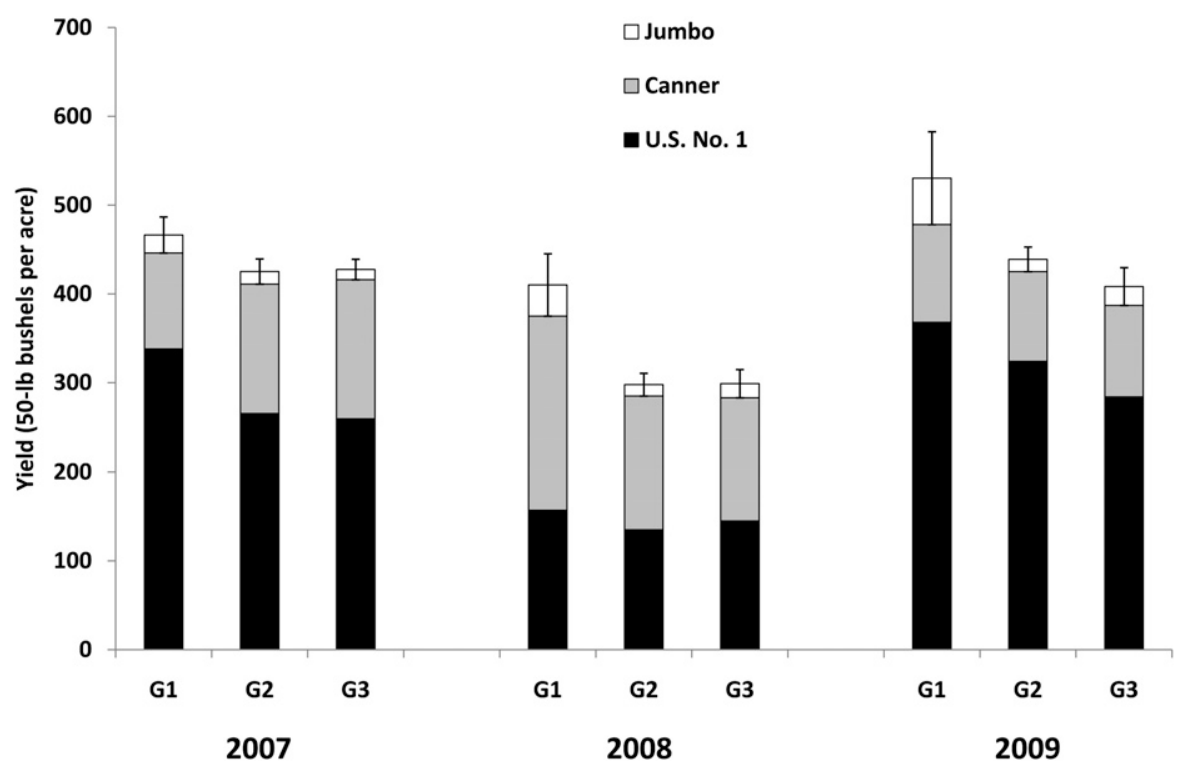

Fig. 2. Yields by grade for 'Beauregard' sweetpotato planted from different generations of seed. U.S. Department of Agriculture standard grades were determined based on size: U.S. No. 1 = roots $2-3 \frac{1}{2}$ inches in diameter and 3-9 inches in length; canner = roots 1-2 inches in diameter and 2-7 inches in length; jumbo $=$ roots that exceed the diameter, length, and weight requirements of the U.S. No. 1 and canner grades; and total marketable = sum of U.S. No. 1, canner, and jumbo grades $(1 \mathrm{inch}=2.54 \mathrm{~cm})$. Gl represents the foundation seed produced during the first year in the field at the Sweet Potato Research Station (Chase, LA); G2 and G3 represent seed produced by growers after 1 or 2 subsequent years in the field on their farms, respectively [error bars $=\mathrm{SE}$ for total marketable yield, which is the sum of U.S. No. 1, canner, and jumbo grades represented in the bar sections; one 50-lb $(22.7-\mathrm{kg})$ bushel per acre $\left.=56.0426 \mathrm{~kg} \cdot \mathrm{ha}^{-1}\right]$. 
B-14 and B-63 mericlones (Table 1). Since the samples obtained were balseed of one mericlone generally provided old seed of the same mericlone) and since the mericlones did not generally differ in the parameters measured, data for the different mericlones of 'Beauregard' were combined.

Year had the greatest effect on yields when compared with other parameters included in the analysis (Table 1). Since yields were measured at a single location each year, it is not possible to assess what aspects of the environment were responsible for the significant year effect. Temperature and rainfall summaries for each year of the study at Burden Center are given in Table 2. There was also a significant difference in U.S. No. 1 yield between seed obtained from northern and southern Louisiana (78.9\% and $97.1 \%$ of Gl for northern and southern Louisiana seed, respectively). This suggests that factors in the environment in which the seed were produced, as well as direct effects of environment on yield in the test plots, affected yield. Year also had a significant effect on incidence of SPVG and SPFMV, both of which were greater in 2009 than in 2007. Yields were greater in 2009, but the differences in yields among generations were also greater in 2009 (Fig. 2). These data indicate that there may be significant differences from year to year in the quality of seed produced at the same location. anced (i.e., growers who provided new

VT seed, which has been available to growers in Louisiana since 1999 , provides better opportunities for good consistent yields than were realized before the advent of the program when no effort was made to limit virus incidence. Unfortunately, we were unable to obtain seed older than G4 from commercial farms and only a few samples of G4 were available for use in this study, suggesting the possibility that growers have become more conscientious about renewing their seed since the introduction and availability of VT seed. It is unknown how much further yield might decline in generations past G3G4. Although there were not enough G4 samples to include in the mixed models analysis, the yield of U.S. No. 1 for G4 was $74 \%$ of $\mathrm{Gl}$, suggesting that yield may further decline beyond G2G3. Before the advent of the VT seed program, growers purchased foundation seed that had been exposed to virus infection for many years. They then used that infected foundation seed to produce the seed for the crop they intended to plant 2 years later. Given the rate of increase of virus incidence over generations observed in this and other studies (Bryan et al., 2003a), and virus incidence found in informal surveys (C.A. Clark, unpublished data), it is likely that foundation seed before 1999 had a very high incidence of all three potyviruses and may have had infections with other viruses as well. When seed from commercial farms was

Table 2. Mean maximum and minimum temperatures and cumulative rainfall recorded by the Louisiana Agriclimatic Information System at the Burden Center of the Louisiana State University Agricultural Center in Baton Rouge for the growing periods during the study of the performance of sweetpotato foundation seed (Louisiana State University Agricultural Center, 2010).

\begin{tabular}{|c|c|c|c|c|}
\hline \multirow[b]{2}{*}{$\underline{\text { Yr }}$} & \multirow{2}{*}{$\begin{array}{c}\text { Days after } \\
\text { planting }\end{array}$} & \multicolumn{2}{|c|}{ Daily mean temp $\left({ }^{\circ} \mathbf{F}\right)^{\mathrm{z}}$} & \multirow{2}{*}{$\begin{array}{c}\text { Cumulative } \\
\text { rainfall (inches) } \\
\end{array}$} \\
\hline & & Maximum & Minimum & \\
\hline \multirow[t]{4}{*}{2007} & $1-30$ & 88.0 & 65.7 & 3.41 \\
\hline & $31-60$ & 93.0 & 72.1 & 7.45 \\
\hline & $61-90$ & 93.2 & 73.4 & 4.25 \\
\hline & $91-99$ & 97.3 & 74.6 & 0.11 \\
\hline \multirow[t]{4}{*}{2008} & $1-30$ & 90.0 & 69.3 & 7.31 \\
\hline & $31-60$ & 92.3 & 70.6 & 3.99 \\
\hline & $61-90$ & 93.6 & 73.3 & 5.39 \\
\hline & $91-107$ & 89.3 & 72.3 & 8.61 \\
\hline \multirow[t]{4}{*}{2009} & $1-30$ & 88.6 & 67.7 & 0.41 \\
\hline & $31-60$ & 95.8 & 75.2 & 6.27 \\
\hline & $61-90$ & 93.3 & 73.3 & 1.52 \\
\hline & $91-107$ & 90.2 & 69.2 & 0.72 \\
\hline
\end{tabular}

${ }^{\mathrm{z}}$ Mean of the daily maximum or minimum temperature for the indicated days after planting $;\left({ }^{\circ} \mathrm{F}-32\right) \div 1.8={ }^{\circ} \mathrm{C}$ ${ }^{\mathrm{y}} 1$ inch $=2.54 \mathrm{~cm}$. subjected to meristem-tip culture and the resulting VT plants were compared with the original seed, it was estimated that viruses were then causing yield declines ranging as high as $25 \%$ to $40 \%$ (Carroll et al., 2004). Thus, although potyvirus re-infection occurs very rapidly and may cause some decline in seed quality despite the use of current VT seed technology, it appears to perform better than seed before the adoption of this technology.

Although it appears that VT seed are beneficial to growers, it is also evident from the data in this study that there is a decline in performance once this seed is increased on commercial farms in close proximity to older, infected propagating material. If the rate of virus re-infection on farms could be reduced, it appears that further improvements in yield could be realized. The likelihood of reducing re-infection by SPFMV appears daunting, but perhaps since the yield decline does not appear to be directly related to SPFMV infection, other viruses should be targeted. There have been very few studies on how to reduce virus spread in sweetpotato. An earlier study indicated that isolation could be used to reduce infection (Martin and Kantack, 1960), but few growers have fields on their farms that could be used for effective isolation from the rest of their crop. Future studies should investigate methods that have proven useful on other crops, such as border crops, and the use of stylet oil sprays to reduce virus transmission. Future efforts should also consider augmenting clean seed programs with enhanced virus resistance, tolerance, or both.

\section{Literature cited}

Bryan, A.D., Z. Pesic-van Esbroeck, J.R. Schultheis, K.V. Pecota, W.H. Swallow, and G.C. Yencho. 2003a. Cultivar decline in sweetpotato: I. Impact of micropropagation on yield, storage root quality, and virus incidence in 'Beauregard'. J. Amer. Soc. Hort. Sci. 128:846-855.

Bryan, A.D., J.R. Schultheis, Z. Pesic-van Esbroeck, and G.C. Yencho. 2003b. Cultivar decline in sweetpotato: II. Impact of virus infection on yield and storage root quality in 'Beauregard' and 'Hernandez'. J. Amer. Soc. Hort. Sci. 128:856863.

Carroll, H.W., A.Q. Villordon, C.A. Clark, D.R. La Bonte, and M.W. Hoy. 2004. Studies on Beauregard sweetpotato 
clones naturally infected with viruses. Intl. J. Pest Mgt. 50:101-106.

Clark, C.A. and M.W. Hoy. 2006. Effects of common viruses on yield and quality of Beauregard sweetpotato in Louisiana. Plant Dis. 90:83-88.

Clark, C.A., R.A. Valverde, S. Fuentes, L.F. Salazar, and J.W. Moyer. 2002. Research for improved management of sweetpotato pests and diseases: Cultivar decline. Acta Hort. 583:103-112.

Dangler, J.M. 1994. Sweetpotato foundation programs provide sweetpotato growers with high-quality pathogen-free seedstock. HortTechnology 4:224.

Hammond, A., M. Cannon, and C.A. Clark. 2001. Crop profile for sweet potatoes in Louisiana. 7 Sept. 2010. <http:// www.ipmcenters.org/cropprofiles/docs/ LAsweetpotatoes.html>.

Hinson, R.A. and J.E. Boudreaux. 2009. 2009 Projected commodity costs and returns, Louisiana vegetable crops.
A.E.A. Info. Ser. No. 263, Dept. Agr. Econ. Agribusiness, Louisiana State Univ, Agr. Ctr., Baton Rouge.

Jester, W.R., C.W. Averre, and J.G. Driver. 1994. Sweetpotato russet crack and micropropagated plants, 1993. Biol. Cult. Tests 9:49.

La Bonte, D., C. Clark, A. Villordon, J. Cannon, M. Hoy, M. Sistrunk, E. Freeman, and G. Roberts. 2004. Yield of four generations of virus-tested sweetpotato. HortTechnology 14:320-322.

Louisiana State University Agricultural Center. 2010. Louisiana Agriclimatic Information System. 26 Oct. 2010. <http:// weather.lsuagcenter.com/>.

Lucier, G. and R. Dettman. 2008. Vegetables and melons outlook/VGS-326, 17 Apr. 2008. U.S. Dept. Agr., Econ. Res. Serv., Washington, D.C.

Martin, W.J. and E.J. Kantack. 1960. Control of internal cork of sweet potato by isolation. Phytopathology 50:150-152.
Stoddard, C.S., K.M. Klonsky, and R.L. DeMoura. 2006. Sample costs to produce sweetpotatoes. Univ. Calif. Coop. Ext. Bul. PO-SJ-06.

U.S. Department of Agriculture. 2005. United States standards for grades of sweetpotatoes. 7 Sept. 2010. <http://www.ams. usda.gov/AMSvl.0/getfile? $\mathrm{dDocName}=$ STELPRDC5050330>.

U.S. Department of Agriculture. 2010. United States and all states crop data. 7 Sept. 2010. <http://www.nass.usda.gov/ Data_and_Statistics/Quick_Stats/>.

Valverde, R.A., C.A. Clark, and J.P.T. Valkonen. 2007. Viruses and virus disease complexes of sweetpotato. Plant Viruses 1:116-126.

Villordon, A.Q., J.M. Cannon, H.L. Carroll, J.W. Franklin, C.A. Clark, and D.R. LaBonte. 2003. Sweetpotato 'Beauregard' mericlones vary in yield, vine characteristics, and storage root size and shape attributes. HortScience 38:1089-1092. 